\title{
Phytoprotection
}

\section{Remise de la Bourse du centenaire SPPQ 2008 Margaret-Newton}

phytoprotection

\section{Denis Pageau}

Volume 89, numéro 2-3, décembre 2008

Journée commémorative du centenaire de la société de protection des plantes du Québec

Centennial Commemoration of the Québec Society for the Protection

of Plants

URI : https://id.erudit.org/iderudit/038246ar

DOI : https://doi.org/10.7202/038246ar

Aller au sommaire du numéro

Éditeur(s)

Société de protection des plantes du Québec (SPPQ)

ISSN

0031-9511 (imprimé)

1710-1603 (numérique)

Découvrir la revue

Citer ce document

Pageau, D. (2008). Remise de la Bourse du centenaire SPPQ 2008

Margaret-Newton. Phytoprotection, 89(2-3), 139-141.

https://doi.org/10.7202/038246ar 


\title{
Remise de la Bourse du centenaire SPPQ 2008 Margaret-Newton
}

\author{
Denis Pageau ${ }^{1}$
}

PHYTOPROTECTION 89 : 139-141

À l'occasion de son centenaire, la Société de protection des plantes du Québec (SPPQ) offre la Bourse du centenaire SPPQ 2008 Margaret-Newton. Cette bourse est décernée en l'honneur de la première femme membre de la Société de protection des plantes du Québec. Dre Newton a été une pionnière de la recherche sur la rouille noire des graminées (Puccinia graminis) et a été la première Canadienne à décrocher un doctorat en agronomie.

La Bourse du centenaire SPPQ 2008 MagaretNewton est offerte à un(e) étudiant(e) inscrit(e) à un programme de maîtrise ou de doctorat d'une université québécoise et dont le projet de recherche est directement associé à la phytoprotection. Un jury composé d'experts en phytoprotection (Dre Anne Légère, malherbologiste, Centre de recherches d'Agriculture et Agroalimentaire Canada (AAC) à Saskatoon; Dr Guy Boivin, entomologiste, Centre de recherche et de développement en horticulture d'AAC à Saint-Jean-sur-Richelieu; Dr André Lévesque, phytopathologiste, Centre de recherches de l'Est sur les céréales et les oléagineux d'ACC à Ottawa) et des membres du comité des bourses étudiantes (Denis Pageau, Daniel Dostaler, Sylvie Rioux, Anne-Marie Simao-Baunoir et Valérie Gravel) a procédé à I'évaluation des candidatures sur la base des critères de l'excellence académique, du potentiel et des aptitudes à la recherche ainsi que des lettres d'appui. Un total de 26 candidatures provenant de plusieurs universités québécoises ont été reçues dans les domaines de la malherbologie, la phytopathologie, la nématologie et l'entomologie.

La récipiendaire de la bourse est Mme Marie-Ėve Bérubé, étudiante au deuxième cycle du programme de biologie végétale au Département de phytologie de l'Université Laval. Madame Bérubé étudie I'impact du glyphosate et du travail du sol sur l'incidence de la fusariose de l'épi chez le blé et l'orge. Les membres du jury tiennent à féliciter Mme Bérubé pour l'excellence de son dossier et remercient également les étudiantes et étudiants qui ont manifesté un grand intérêt pour la Bourse d'études du centenaire SPPQ 2008 Magaret-Newton.

Candidatures:

- Arsenault-Labrecque, Geneviève. $2^{\mathrm{e}}$ cycle. Département de phytologie, Université Laval

- Aubry, Olivier. $3^{\text {e }}$ cycle. Département des sciences biologiques, Université du Québec à Montréal (UQAM)

1. Président du comité 2008 des bourses étudiantes de la SPPQ

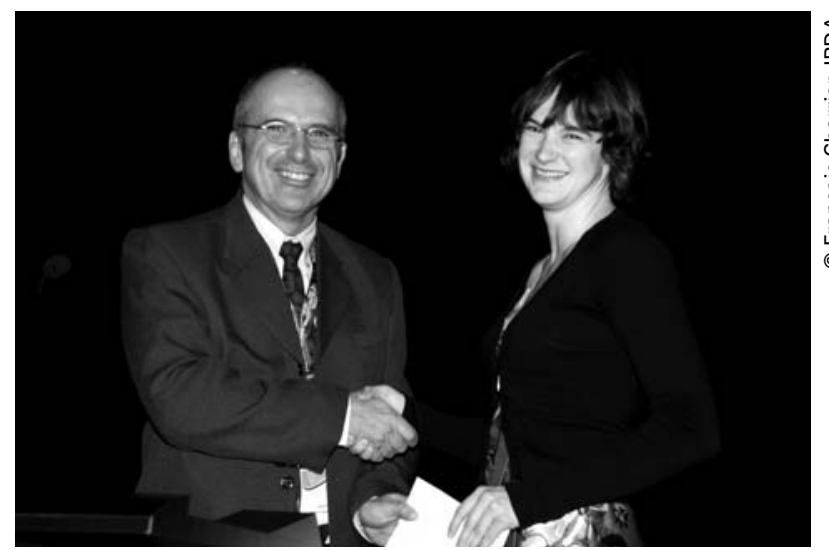

Denis Pageau et Marie-Ėve Bérubé

- Bastien, Maxime. $3^{\mathrm{e}}$ cycle. Département de phytologie, Université Laval

- Bélanger, Sébastien. $2^{\mathrm{e}}$ cycle. Département des sciences du bois et de la forêt, Université Laval

- Bernier-English, Valérie. $2^{\text {e }}$ cycle. Département de phytologie, Université Laval

- Bérubé, Marie-Ėve. $2^{\text {e }}$ cycle. Département de phytologie, Université Laval

- Clermont, Nancy. $3^{e}$ cycle. Département de biologie, Université de Sherbrooke

- Fournier, Cédric. $2^{\mathrm{e}}$ cycle. Département des sciences du bois et de la forêt, Université Laval

- Gagné, Geneviève. $2^{\mathrm{e}}$ cycle. Department of Plant Science, McGill University

- Gauthier, Mélanie. $2^{e}$ cycle. Département de phytologie, Université Laval

- Grégoire, Caroline. $2^{\text {e }}$ cycle. Département de phytologie, Université Laval

- Hock, Virginia. $3^{\mathrm{e}}$ cycle. Département des sciences biologiques, Université du Québec à Montréal (UQAM)

- Jinek, Andréa. $2^{\mathrm{e}}$ cycle. Département de phytologie, Université Laval

- Joly, David L. $3^{\text {e }}$ cycle. Département des sciences du bois et de la forêt, Université Laval

- Lalonde, Olivier. $2^{\mathrm{e}}$ cycle. Département de phytologie, Université Laval 
- Légaré, Jean-Philippe. $2^{\mathrm{e}}$ cycle. Département des sciences du bois et de la forêt, Université Laval

- Legault, Geneviève. $2^{\mathrm{e}}$ cycle. Département de biologie, Université de Sherbrooke

- Lemaire, Émilie. $2^{\mathrm{e}}$ cycle. Département de phytologie, Université Laval

- Longchamps, Louis. $3^{e}$ cycle. Département de phytologie, Université Laval

- Mader, Brian. $2^{\text {e }}$ cycle. Department of Biology, Concordia University

- Maheux, Émilie. $2^{\mathrm{e}}$ cycle. Département de sciences biologiques, Université de Montréal
- Maisonhaute, Julie-Éléonore. $2^{\mathrm{e}}$ cycle. Département des sciences biologiques, Université du Québec à Montréal (UQAM)

- McClure, Mélanie. $3^{\mathrm{e}}$ cycle. Department of Biology, Concordia University

- Morisset, Olivier. $2^{\mathrm{e}}$ cycle. Département des sciences biologiques, Université du Québec à Montréal (UQAM)

- Quezada-Garcia, Roberto. $3^{\mathrm{e}}$ cycle. Département des sciences du bois et de la forêt, Université Laval

- Robert, Louis-Étienne. $3^{\mathrm{e}}$ cycle. Département des sciences biologiques, Université du Québec à Montréal (UQAM)

\section{Margaret Newton, phytopathologiste (1887-1971)}

Née à Montréal (Québec) en 1887, Margaret Newton, à sa sortie du Collegiate Institute de Vankleek Hill (Ontario), enseigne pendant plusieurs années en vue de réunir les fonds nécessaires pour entreprendre des études universitaires. Après un an à McMaster University, Hamilton (Ontario), elle opte pour I'agriculture au Collège Macdonald de I'Université McGill.

Margaret Newton excelle dans ses études au Collège Macdonald et remporte à la fin de sa deuxième année la médaille de bronze du Gouverneur général. La même année, elle s'intéresse à la rouille, maladie qui s'attaque aux plantes, et décide de se spécialiser en phytopathologie. À cette fin, elle s'inscrit à la Société de protection des plantes du Québec, devenant ainsi la première femme membre de cette société. En complément à ses études, elle joue un rôle actif au sein du club de discussion et préside le club littéraire de sa classe.

En 1918, Margaret Newton obtient son baccalauréat en sciences agricoles. Elle devient ainsi la première femme à terminer ce programme d'études au Collège Macdonald et se hisse au rang des premières femmes au Canada à détenir un diplôme universitaire en agriculture. L'année suivante, toujours au Collège Macdonald, elle obtient une maîtrise en sciences. Au cours de ses études, elle entreprend des travaux de recherche sur la rouille noire des graminées (Puccinia graminis), notamment chez le blé. Ces travaux la conduisent à l'University of Saskatchewan, où elle est nommée chercheure, et à I'University of Minnesota, où elle poursuit ses études de doctorat. En 1922, elle devient la première Canadienne à obtenir un doctorat en agronomie.

Dans l'intervalle, il s'est créé à Winnipeg un laboratoire sur la rouille noire, multipliant ainsi les possibilités de recherches dans ce domaine. Dre Newton accepte avec plaisir l'invitation du ministre fédéral de l'Agriculture de le diriger. Elle publie plus de 40 articles sur le $P$. graminis et participe à la rédaction du journal Phytopathology. Les avantages économiques dérivés de ses travaux sont considérables. À sa retraite, les pertes annuelles causées par la rouille

\section{Margaret Newton, plant pathologist (1887-1971)}

Born in Montréal (Quebec) in 1887, Margaret Newton taught for several years after completing her schooling and qualifying as a teacher at the Collegiate Institute in Vankleek Hill (Ontario). This provided her with the funds to enter university. After spending one year at McMaster University in Hamilton (Ontario), she decided to study agriculture at McGill University's Macdonald College.

Newton did well in her studies at Macdonald College and won the Governor General's bronze medal for highest standing at the end of her second year. That same year, she became interested in rust diseases in plants and decided to focus on plant pathology. To that end, she joined the Québec Society for the Protection of Plants, becoming its first woman member. She complemented her studies with outside activities, being active in the Debating Society and president of the class Literary Society.

In 1918, Newton graduated with a Bachelor of Science in Agriculture, the first woman to complete all the degree requirements at Macdonald College and one of the first women in Canada to earn a degree in agriculture. She followed this with a Master of Science degree in 1919, also from Macdonald College. During her course of study for both degrees, she had undertaken research on grain (cereal) rusts (Puccinia graminis) with emphasis on wheat. This led to a research position at the University of Saskatchewan and doctoral studies at the University of Minnesota, upon completion of which she became the first Canadian woman to earn a Ph.D. in agricultural sciences, in 1922.

The creation of a rust laboratory in Winnipeg led to more research opportunities and Margaret Newton was pleased to accept the invitation of the federal Minister of Agriculture to take charge of the new facility. She wrote more than 40 papers on rust fungi and assisted in editing the journal Phytopathology. The economic significance of her research can be seen in the reduction of annual losses of wheat due to rust from 30 million bushels to practically none at the time of her retirement. 
noire sont passées de 30 millions de boisseaux à des niveaux presque négligeables.

Les travaux de Dre Newton connaissent une véritable consécration lorsqu'elle est nommée Membre de la Société royale du Canada en 1942, devenant ainsi la deuxième femme à se voir investie d'un tel honneur. En 1948, elle reçoit la Médaille Flavelle de la Société, faisant d'elle la première femme et la première diplômée en agronomie à recevoir cette distinction. En 1956, I'University of Minnesota lui décerne son prix pour réalisations exceptionnelles et, en 1964, I'University of Victoria rebaptise l'une de ses résidences pour lui donner le nom de "Margaret Newton Hall ".

Margaret Newton s'est éteinte en 1971 à Victoria, en Colombie-Britannique.

Courtoisie de: Pionnières canadiennes - La Fondation canadienne pour l'innovation

[http://www.innovationcanada.ca].

\section{Sources et autres liens}

Estey, R.H. 1983. Histoire de la Société de protection des plantes du Québec. Phytoprotection 64: 1-22.

Estey, R.H. 1987. Margaret Newton: Distinguished Canadian scientist and first woman member of the Québec Society for the Protection of Plants. Phytoprotection 68: 79-85.

Margaret Newton, Pioneering Woman in Plant Pathology of the American Phytopathological Society (APSnet Features).

[http://www.apsnet.org/online/feature/newton]

[http://www.apsnet.org/online/feature/newton/links.asp]
Dr. Newton's work was acknowledged in her election as Fellow of the Royal Society of Canada in 1942, only the second woman to receive such an honour. In 1948, she received the Society's Flavelle Medal, the first woman to receive this award and also the first graduate of an agricultural college to be awarded that medal. In 1956, the University of Minnesota granted her its Outstanding Achievement Award and, in 1964, the University of Victoria named one of its residences "Margaret Newton Hall".

Margaret Newton died in 1971 in Victoria, British Columbia.

Courtesy of: Canadian Pioneers - Canada Foundation for Innovation [http://www.innovationcanada.ca/].

\section{Sources and other links}

Estey, R.H. 1983. A History of the Québec Society for the Protection of Plants. Phytoprotection 64:1-22.

Estey, R.H. 1987. Margaret Newton: Distinguished Canadian Scientist and first woman member of the Québec Society for the Protection of Plants. Phytoprotection 68: 79-85.

Margaret Newton, Pioneering Woman in Plant Pathology of the American Phytopathological Society (APSnet Features). [http://www.apsnet.org/online/feature/newton] [http://www.apsnet.org/online/feature/newton/links.asp] 